\title{
Socio - Economic Factors Affecting Retention of the Boy-Child in Secondary Schools of Mathioya, Kenya
}

\author{
Felicita W. Njuguna $^{1} \quad$ Peter N. Muchanje ${ }^{2}$ \\ School of Education, Department of Educational Management, Policy and Curriculum Studies, Kenyatta \\ University, P.O. Box 43844-00100, Nairobi, Kenya
}

\begin{abstract}
The Government of Kenya (GoK) has continuously provided grants to secondary schools to retain all children in school. However, there have been challenges in internal efficiency in form of boy child retention in schools. The main objective was to determine the socio-economic factors influencing retention of boy child in secondary schools in Mathioya Sub - County between 2005 and 2011. A descriptive survey design was used in this study. The researchers used stratified, simple random and purposive sampling to get a sample of 9 schools, 9 principals, 180 students, 54 teachers and 36 parents, Sub-County Education Officer (D.E.O) and Sub-County Quality and Assurance Officer. The study used questionnaires for principals and teachers, interviews were conducted for parents /guardians while Focus Group Discussion (FGD) was used to collect information from students. Quantitative data was analysed descriptively using frequency counts, percentages, frequency tables and bar graphs. Qualitative data was analysed thematically. Despite Free Day Secondary Education (FDSE), boys continued to drop out of schools. The study recommends that the government should unite with other stakeholders to conduct aggressive campaigns to sensitize community on importance of educating all children. Most important the GoK should unsparingly deal with the militia groups like Mungiki.
\end{abstract}

Keywords: Boy child, Retention, Education for All, Militia group, Social and Economic activities

DOI: $10.7176 / \mathrm{JEP} / 10-29-10$

Publication date:October $31^{\text {st }} 2019$

\section{Background of the study}

Education and training remain the foremost tools for accelerating social and economic development for industrialization in the $21^{\text {st }}$ Century as projected (Republic of Kenya, 2003). Good performance in education, training and research sectors immensely contribute to any country's development. Performing education sectors produce appropriate human resource capital that is integral in spurring productivity (MOEST, 2005). In this regard, education is considered as a key determinant of earnings and an important exit route from poverty. Recent studies of human capital returns in Kenya show that capital returns increase as the level of education goes higher. Education is further seen as a vehicle in reduction of social and economic inequalities. Hence, government involvement in education and training is justified on the basis that human capital development has large social returns, (MOEST, 2005). It is in this regard that the Kenyan Government is committed to the provision of equal access to quality and relevant education and training opportunities to all Kenyans. As documented in universal declaration of Human Rights (1948), the United Nations Convention on Rights of the Child (1989), 1990 African Charter on the Rights and Welfare of the Child, Salamanca Statement 1994, the Millennium Development Goals (MDG), (UNESCO, 2000), sessional paper no.1 of 2005 and Education For All (EFA) by 2015, the country has embraced education as a basic human right.

The KENYA INSTITUTE FOR PUBLIC POLICY RESEARCH AND ANALYSIS (KIPPRA) Report (2009), shows that gender disparities in participation in Kenya differ by regions. The report shows that the enrolment in Nairobi and Central Provinces has fallen despite free learning programmes introduced in 2003 for primary and 2008 for secondary schools. It further states that, though 1.3 million students enrolled in secondary schools many are thought to have left the institutions in spite of the free day learning programme. According to the Report, an increasing number of boys in former Central Province are dropping out of school to seek salaried jobs to boost family income. Ministry of Education (MOE) statistics of 2009 show that more boys than girls enroll in the primary schools but their number decreases gradually as years go by so that they are outnumbered by girls. The figures gradually change at secondary level in favour of girls and with significant margin. The Table 1.1 and 1.2 below indicate the number of students who enrolled and who completed secondary schools in Mathioya by gender in 2005 to 2011 respectively. 
Table 1.1 Number of Students who enrolled in Public Secondary School in Mathioya by Gender (2005-2011)

\begin{tabular}{llll}
\hline Years & Boys & Girls & Total \\
\hline $\mathbf{2 0 0 5}$ & 2780 & 2854 & 5634 \\
$\mathbf{2 0 0 6}$ & 2361 & 2968 & 5329 \\
$\mathbf{2 0 0 7}$ & 2690 & 3192 & 5882 \\
$\mathbf{2 0 0 8}$ & 3120 & 3764 & 6884 \\
$\mathbf{2 0 0 9}$ & 3567 & 4095 & 7662 \\
$\mathbf{2 0 1 0}$ & 3907 & 4426 & 8333 \\
$\mathbf{2 0 1 1}$ & 4563 & 4801 & 9364 \\
\hline
\end{tabular}

Source: Sub-County Education Office Mathioya (2011)

Table 1.2: Number of Students who Completed Secondary School in Mathioya Sub-County by Gender (2005-

\begin{tabular}{llll} 
& & & \\
\hline Year & Boys & Girls & Total \\
\hline $\mathbf{2 0 0 5}$ & 690 & 862 & 1552 \\
$\mathbf{2 0 0 6}$ & 674 & 804 & 1478 \\
$\mathbf{2 0 0 7}$ & 712 & 810 & 1522 \\
$\mathbf{2 0 0 8}$ & 790 & 885 & 1675 \\
$\mathbf{2 0 0 9}$ & 915 & 950 & 1865 \\
$\mathbf{2 0 1 0}$ & 603 & 810 & 1413 \\
$\mathbf{2 0 1 1}$ & 829 & 1163 & 1992 \\
\hline
\end{tabular}

Source: Sub-County Education Office Mathioya (2011)

This emerging trend of boys' low enrolment and completion needs attention and this has prompted the researchers to find out the factors behind the low retention of boy child in public secondary schools in MOE, Murang'a County. As recorded by Orodho (2005), solving the problem of high dropouts will help the government to attain Universal basic Education For All [EFA]. This can help the country to enhance its drive for attaining 100per cent transition rate in the education system and achieving industrialized country by the year 2030 . The study therefore sought to find out the socio-economic factors that push boys out of school in Mathioya, Murang'a County.

\subsection{Objectives of the study}

The research focused on achieving the following specific objectives

1. To determine the economic factors that hinder retention of the boy-child in secondary school education in Mathioya Sub-County

2. To determine the social factors that hinder retention of the boy-child in secondary school education in Mathioya.

3. To establish measures that can improve retention of the boy-child in secondary schools in order to enhance the achievement of Education for All (EFA) goals.

\subsection{Research Questions}

The research was guided by the following research questions

1. What are the economic factors that have led to low retention of the boy -child in the study Sub-County?

2. What are the social factors that have led to low retention of the boy -child in the study Sub-County?

3. What measures could be taken to improve retention of boys in public secondary schools in order to enhance the achievement of EFA goals?

\subsection{Research Methodology}

\subsection{Research Design}

The researchers used a descriptive survey design to investigate the factors that affect retention of the boy-child in secondary schools in Mathioya. According to Borg and Gall (1989), descriptive survey research is intended to produce statistical information about aspects of education. Mugenda and Mugenda (2003) states that descriptive survey design is the best method available to social scientists who are interested in collecting original data for the purpose of describing a population which is too large to observe directly.

\subsection{Target Population}

The study targeted the school going boys in Mathioya Sub-County Public Secondary Schools aged between 14-18 years, secondary school principals, teaching staff, parents, and government officials in Ministry of Education and the Office of the President in the Sub-County. The target population included: 25 principals in public secondary schools, 3907 secondary school boys from Form 1 to 4, 265 teaching staff, 36 parents/guardians and 2 
administration officials in Mathioya.

\subsection{Research Sample}

The research sample was summarized below-:

(i) Two Boys Boarding Schools, Six Mixed Day Schools, One Mixed Boarding and Day school will be stratified and randomly sampled making a total of nine out of twenty five secondary schools which constitutes 36per cent of the target population.

(ii) Twenty students were randomly selected from each of the sampled secondary schools, to make a total of 180boys

(iii) All the principals of the nine schools took part in the study.

(iv) Six teachers were randomly sampled from each of the sampled secondary schools making a total of 54 teachers.

(v) Two parents/guardians of the sampled schools whose boys were enrolled in secondary school and two parents who had no children in the school but within the reach of the sampled schools were sampled purposively making a total of 36 parents.

(vi) The D.E.O and DQASO were purposively included in the sample.

(v) Key informants were included in the study since they interact with the community and were in a position to provide in depth information on the factors influencing retention in the study Sub-County. These included the provincial administration in the sub - county.

\subsection{Research Instruments}

The researchers used questionnaire to gather information from teachers and head teachers, interview schedules to gather information from parents/guardians and key informants. Focus Group Discussion (FGD) guides were used to gather information from the students. These instruments were developed by the researchers in accordance to guidelines by Orodho (2008).

\subsection{Reliability of the Instruments}

Orodho (2008) defines reliability of an instrument as the consistency in producing a reliable result. An instrument is reliable if it gives similar results after several administrations under similar conditions. The researchers used test-retest method to test for reliability of research instruments. The two results were compared/ correlated using the Pearson's coefficient correlation where a positive coefficient of 0.82 was considered high enough to judge the reliability of the instrument (Orodho, 2008).

\subsection{Validity of the Instruments}

Orodho (2008), defines validity as the degree to which results obtained from analysis of the data actually represents the phenomenon under investigation. The researchers used content validity to assess validity of the instruments. Content validity is the degree to which the sample of the test represents the content that the test is designed to measure (Orodho, 2008). The researchers selected a panel of three experts competent in the area of study to assess the relevance of the content used in the questionnaire developed. They examined the questionnaire and provided feedback to the researchers and then recommendations were incorporated in the final questionnaire (Orodho, 2008).

\subsection{Data Collection Procedure}

The researchers got research permit from MOE to conduct research which was used to introduce the researchers at all levels of target population. The researchers booked appointments with target respondents and administered the research instruments as per category.

\subsection{Data Analysis Methods}

The Statistical Package for Social Sciences (SPSS) was used to analyze descriptive data because of its ability to handle large amount of data. The data from interviews and focus group discussions were read carefully paying attention to comments, ideas, concern from the participant and conclusions were drawn based on theme of the study. Data was presented using frequencies distribution tables, percentages and graphs.

\subsection{Research Findings}

\subsection{Category and Types of the Sampled Schools}

The researchers categorized the schools into two that is Sub-County and Provincial schools. The Sub-County schools took care of County and day schools while provincial took care of extra county and national schools. Figure 3.1 below presents category and types of sampled schools. 


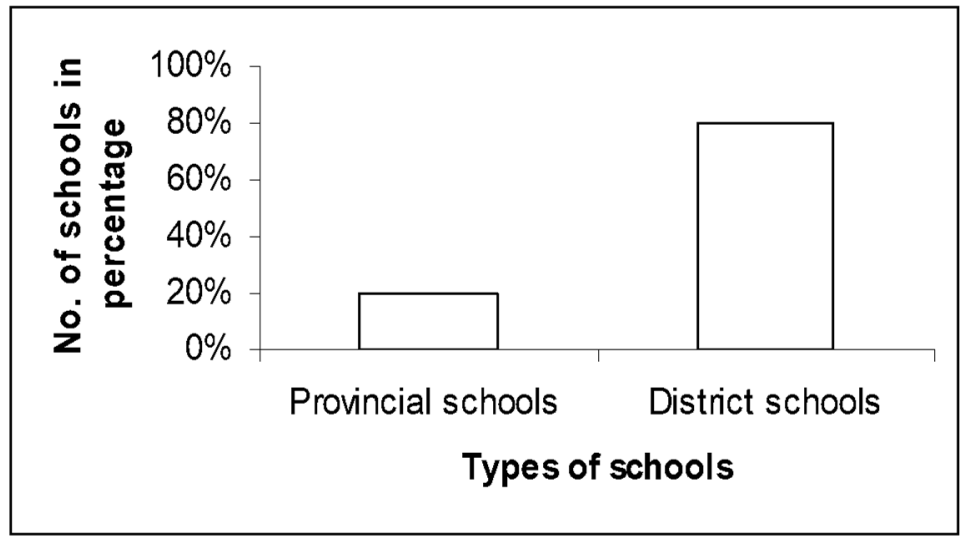

Figure 3.1 Categories of the Sampled Schools

The researchers sampled 9 (36per cent) out of 25 public secondary schools in the study Sub-County. Among the sampled schools, only 2 (22.22per cent) were provincial schools while the other 7 (77.78per cent) were in SubCounty schools category.

Table 3.1 Type of the Sampled Schools

\begin{tabular}{|c|c|c|c|}
\hline Types of schools & Frequency & $\begin{array}{l}\text { No. of students } \\
\text { respondents }\end{array}$ & $\begin{array}{lll}\begin{array}{l}\text { Percentage } \\
\text { respondents }\end{array} & \text { of } & \text { student } \\
\end{array}$ \\
\hline Boys' boarding & 2 & 40 & 22.22per cent \\
\hline Mixed boarding & 1 & 20 & 11.11per cent \\
\hline Mixed Day & 6 & 120 & 66.67per cent \\
\hline Total & 9 & 180 & 100.00per cent \\
\hline
\end{tabular}

Table 3.1 indicate that majority of students are vulnerable to the problems associated with day schools. Problems such as unconducive weather, community influence, inadequate space for study at home and walking for long distances to and from school which exhausted the learners. These problems could affect the quality of concentration of learners and their subsequent performance in school. They are likely to deter enrolment and regular attendance and could lead to early drop out (FAWE, 1997).

\subsection{Gender of the Teacher Respondents}

The teacher respondents were asked to indicate their gender. Their responses were as in Table 3.2.

Table 3.2 Gender of Teacher Respondents

\begin{tabular}{lll}
\hline Gender & Frequency & Percentage \\
\hline Male & 23 & 42.59 \\
Female & 31 & 57.41 \\
\hline Total & 54 & 100 \\
\hline
\end{tabular}

It was expected that the male-female teachers would be equal. However as shown in Table 3.2, a gap was observed between the number of male and female teacher respondents. The respondents by gender were 31 (57.41per cent) females and 23 (42.59per cent) males. This may have made male students to lack sufficient role models to guide in their academic work.

\subsection{Enrolment of Students in the Sampled Schools for the Period 2005-2011}

To determine enrolment in the sampled schools, principals were requested to provide data on enrolment of their schools per year for the period 2005-2011. Table 3.3 presents students enrolment in the sampled schools by gender.

Table 3.3 Enrolment in the Sampled Schools for the Period 2005-2011

\begin{tabular}{lllllllll} 
Gender & $\mathbf{2 0 0 5}$ & $\mathbf{2 0 0 6}$ & $\mathbf{2 0 0 7}$ & $\mathbf{2 0 0 8}$ & $\mathbf{2 0 0 9}$ & $\mathbf{2 0 1 0}$ & $\mathbf{2 0 1 1}$ & Total \\
\hline Boys & 750 & 689 & 773 & 770 & 818 & 955 & 1038 & 5793 \\
Girls & 1166 & 1032 & 987 & 1341 & 1499 & 1517 & 1790 & 9332 \\
\hline
\end{tabular}

Table 3.3 reveals that enrolment of students rose sharply from 2008 which could probably be caused by introduction of Free Secondary Education (FDSE) by the government. It also shows that enrolment of boys remained lower than that of girls throughout the period of the study. This could be indication that a lot of emphasis has been put on girls' education than that of boys. The findings agreed with a report by KIPPRA (2009), which stated that parents in Central Province shifting priority from boys' education to that of girls. 
Table 3.4 Enrolment of Boys in Single Sex Schools and Mixed Schools for the Period 2005 - 2011

\begin{tabular}{lll}
\hline Types of School & Number of Boys & Percentage \\
\hline Single Sex Schools & 4670 & 80.61 per cent \\
Mixed Schools & 1123 & 19.39 per cent \\
Total & 5793 & 100.00 per cent \\
\hline
\end{tabular}

Table 3.4 shows that the enrolment of boys in single sex schools was higher, 4670 (80.61per cent) compared to that of mixed schools which was 1123 (19.39per cent). This could be an early indication that enrolment and retention of learners would improve if more single sex schools were established

Students in their discussion confirmed that they were aware of some of their peers in their neighbourhood who had completed primary cycle but had not enrolled in secondary school. They identified various reasons which made their peers not to enroll in secondary schools. The main reasons according to student respondents are presented in Table 3.5.

Table 3.5 Reasons Why Students Did not Enroll in Secondary Schools According to Students

\begin{tabular}{lll}
\hline Reasons & Frequency & Percentage \\
\hline Poverty & 74 & 41 per cent \\
Peer influence & 58 & 32 per cent \\
Negative attitude towards education & 23 & 13 per cent \\
Lack of role models & 16 & 9 per cent \\
Poor parenting & 9 & 5 per cent \\
Total & $\mathbf{1 8 0}$ & 100per cent \\
\hline
\end{tabular}

Table 3.5 shows that majority of students identified poverty 74 (41per cent) and peer influence 58 (32per cent) as major factors that made students not to enroll in secondary schools. Negative attitude towards education was identified by 23 (13per cent) students while lack of role models and poor parenting were identified by 16 (9per cent) and 9 (5per cent) students respectively. Students explained that high poverty level made learners not to be enrolled in secondary schools because they did not have anybody in their families capable of paying for their secondary education. Students explained that majority of their parents were peasant farmers who depended on cheap labour in tea and coffee farms of the few well-up families. Another group of parents depended on sale of farm produce which ranged from milk, maize and vegetables which were only available depending on seasons. Most of their farm products were bought at very low prices. The few who sold their produce through cooperatives had huge loans which made them unable to pay school fee as they repaid the loans. This made most of the parents of Mathioya not to enroll their children in secondary schools while those who had enrolled dropped-out of school. These findings agreed with Sifuna (1980) and Abagi (1997), who found out that economic factors are responsible for high percentage of students not enrolling or leaving secondary schools in Kenya before graduation. Students also got employed so that they could support their poor parents hence child labour. Students' further explained that though the Sub-County was well endowed with resources the irresponsible and uneducated parents were not able to exploit them.

Students explained peer influence was very rampant in the Sub-County. Due to poverty in the Sub-County, boys opted to look for salaried jobs like quarrying, tea picking, coffee picking and being matatu touts to earn their own money. Boys influence one another thus failing to enroll in secondary schools. Students said that their peers who had money at early age did not value education since they felt that education disrupted them from getting their earnings. Students felt that money earned by school going students had negative influence in the community. The money was used in drugs, purchasing of fancy clothes, entertainment joints and purchase of local brew. This encouraged more boys to drop out of school to earn money and "enjoy" like their peers.

\subsection{Situation of drop out in the Sampled Schools}

The situation of drop out was examined with an aim of determining factors that caused it in the sampled schools. Students in their FGD confirmed that some of their peers had dropped out of school due to different reasons. Students' respondents identified such reasons as conflict between teachers and students, conflict among students, family break ups, family conflicts between parents and children, early employment, lack of parental support and peer influence. Much clearer details were got from principal respondents where they were requested to provide the number of dropouts per year in every form for the period 2005-2011. Fifty five percent of principal respondents pointed out that it was difficult to establish the reasons of students who failed to report back to school because some left in the name of transfers while others just failed to report. They also said that the gaps created by those who left schools were filled up by transferees from other schools, so the issue of dropout did not come out clearly. However, 4 (44per cent) of the principal respondents provided the data on the number of students who dropped out in the period 2005-2011 as shown in Table 3.6. 
Table 3.6 Number of Students who dropped out in the Period 2005-2011

\begin{tabular}{lccccccccc}
\hline Schools & $\mathbf{2 0 0 5}$ & $\mathbf{2 0 0 6}$ & $\mathbf{2 0 0 7}$ & $\mathbf{2 0 0 8}$ & $\mathbf{2 0 0 9}$ & $\mathbf{2 0 1 0}$ & $\mathbf{2 0 1 1}$ & Total \\
\hline Dropouts & 48 & 53 & 55 & 41 & 31 & 33 & 30 & 291 \\
\hline
\end{tabular}

It is clear that the number of students dropping out of schools started to decline in 2008 to 2011 . This is an indication that more students were retained in school after the government introduced Free Day Secondary Education (FDSE) in 2008. This could be an early indicator that school fees could have been a major challenge to parents and their children. However, even with FDSE, students continued dropping out of schools. Parents who were interviewed said that schools asked money for private tuition which were offered early in the morning, at night and on Saturday. Ministry of Education Officials said that drop out existed due to negative attitude towards education by students, transfer of students from one public school to another and to private academies, irresponsible parents and indiscipline among students. This could be an indication that due to the extra cost of education which was incurred by parents, families are drained off their financial resources making them unable to cater for the school needs of their children. Eventually students drop-out of schools. The findings agreed with Curle (1973) who showed that there were many hidden costs of attending free schools which Psacharapoulus and Woodhall (1997) identified as out of pocket expenses for clothes and travel. Considering the poverty rate in the country, many parents may fail to enroll or retain their children in secondary schools because they cannot afford those hidden costs of education (Macharia, 2009).

\subsection{Economic Factors that Hinder Retention of the Boy-Child in Secondary Education}

The researchers sought to determine and analyze economic factors affecting retention of the boy-child in Mathioya Secondary Schools. The views were sought from the principals, teachers and students of the sampled schools, parents and Ministry of Education Officials from the Sub-County headquarters. Different variables were examined as indicated in the ensuing paragraph.

\subsubsection{Economic Activities in the Study Region}

Both teachers and Ministry officials were asked to identify the economic activities carried out in Mathioya. Majority of them indicated the following: 41 (73.21per cent) identified small scale farming of tea; coffee; food crops and dairy animals while 15 (26.79per cent) identified small scale business such as Jua kali. The returns from these activities were minimal and therefore insufficient to support the students in school. Over 50per cent of the student respondents pointed out that most of their peers were not enrolled and others dropped out from secondary schools since their parents' finances were not adequate to educate and support their families. This was also confirmed by the parents as indicated in Figure 3.3.

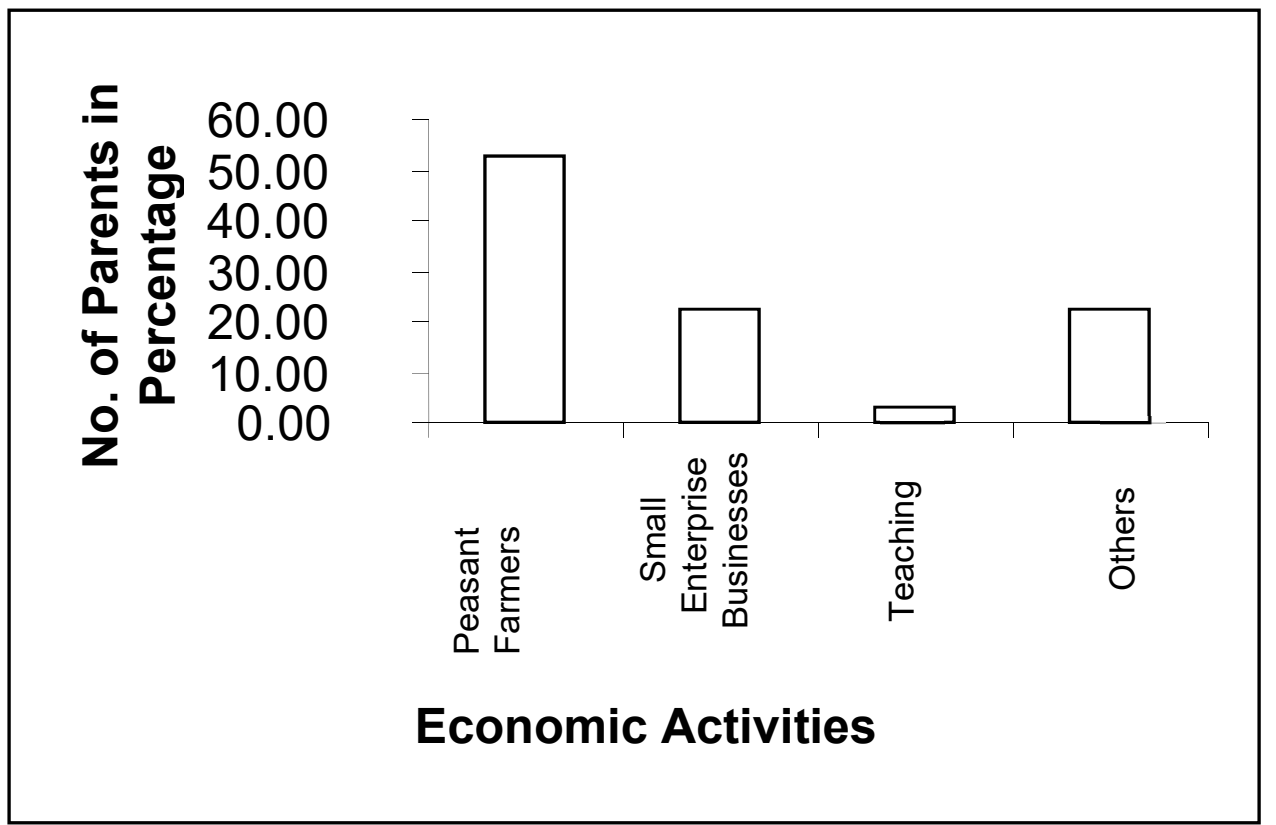

Figure 3.3 Economic Activities in the Sub-County

Parents indicated that economic activities earned them too little to maintain their families both at home and school. They pointed that they needed their children to supplement through getting gainful employment. Figure 4.3 shows that out of 36 parents/guardians interviewed 19 (52.78per cent) were peasant farmers; 8 (22.22per cent) in small enterprise businesses; 1 (2.78per cent) was in teaching while the other 8 (22.22per cent) were in other minor jobs like watchmen and house helps. Sifuna (1978), stated that economic factors were responsible for the 
large percentage of those leaving schools before graduation.

\subsubsection{Effects of Economic Activities on Education of the Boy-Child}

Teachers and Ministry of Education Officer were asked the effect of economic activities on the boy-child education in the study Sub-County. The responses to the questions are presented in Table 3.7.

Table 3.7 Effects of Economic Activities on Education of the Boy-Child

\section{Effects}

Inadequate school fees leading to high dropout

Students leave school to provide labour for harvestin

tea and coffee

Day scholars report late to school after delivery milk 34

to the market

Students pay little attention to education after school 29

\begin{tabular}{ll}
\multicolumn{2}{c}{ Teachers } \\
\hline Frequency & Percentage \\
50 & 92.59 \\
39 & 72.22
\end{tabular}

D.E.O and DQASO

Frequency Percentage

2

2

1

$53.70 \quad 2$

Table 3.7 reveals that economic activities formed a major challenge on education of the boy-child. Inadequate school fees was indicated by 50 (92.59per cent) and 2 (100per cent) of teachers and other informants respectively; students dropping out of school to harvest coffee and tea was indicated by 39 (72.22per cent) of teachers and 2 (100per cent) of other informants. Reporting late was identified by 34 (62.96per cent) of teachers and 15 (50per cent) of the other informants; 29 (53.70per cent) teachers and 2 (100per cent) other informants indicated that boys visualized business activities as superior to education making them to pay little attention to education. The findings agreed with KIPPRA (2009) that a number of boys in Central Province drop out of school to seek salaried jobs. Principals and teachers indicated that children from poor families' dropped out of school more than those from well to do families as shown in Table 3.8 .

Table 3.8: Children from Poorer Families Drop out of School more than those From Well to do Families

\begin{tabular}{lll}
\hline Rating & Frequency & Percentage \\
\hline True/Yes & 51 & 81.25 \\
False-No & 12 & 18.75 \\
Total & 63 & 100 \\
\hline
\end{tabular}

Among the respondents 51 (81.25per cent) agreed while 12 (18.75per cent) disagreed. This could indicate that children dropped out of school due to failure of meeting their educational needs such as buying resource materials. The findings were consistent with Bruns et al (2002) who established that of the richest households, 76 percent of their children attended schools compared to 40 percent of the poor households. This meant that children from poor households had much lower attendance than those from richer ones. The findings of the research agreed with Abagi (1997) who found that children whose parents could not afford cost of institutional materials and uniform tended to go to school irregularly and in long run dropped out of school. Principals and teachers were asked whether family financial status influenced retention since introduction of Free Secondary Education (FDSE). Their responses are presented in Table 3.9.

Table 3.9: Financial Status of the Family does Not Influence Access and Retention since Introduction of Free Secondary Education

\begin{tabular}{lllll}
\hline Rating & \multicolumn{3}{c}{ Principals } & Teachers \\
\cline { 2 - 5 } & Frequency & Percentage & Frequency & Percentage \\
\hline True & 3 & 33.33 & 14 & 25.39 \\
False & 6 & 66.67 & 40 & 74.07 \\
\hline
\end{tabular}

Majority of both principals 6 (66.67per cent) and teachers 40 (74.07per cent) disagreed with the statement. The Table indicates that even with FDSE family financial status continues to influence retention of learners. The FDSE involves cost sharing between the government and parents. Children from poor parents would therefore drop out of school if the parent failed to meet his/her share in the cost of education. The findings agreed with Johnson (1996) who indicated that poverty of parents had elastic effects on their children's education as they lacked enough resources and funds to sponsor their education in good schools, good housing facilities, medical care and social welfare services.

\subsubsection{Cost of Education}

Specific statements were made to the teachers and principals where they were expected to agree or disagree. A perusal through the table on economic factors generated from the findings indicated the responses as shown in Tables 3.10 and 3.11 . 
Table 3.10 There are Still Non-Tuition Costs that Make FDSE Inaccessible to Some Children in the Sub-County

\begin{tabular}{lllll}
\hline & \multicolumn{2}{c}{ Principals } & Teachers \\
\cline { 2 - 5 } Rating & Frequency & Percentage & Frequency & Percentage \\
\hline True & 7 & 77.78 & 36 & 66.67 \\
False & 2 & 22.22 & 18 & 33.33 \\
Total & 9 & 100.00 & 54 & 100 \\
\hline
\end{tabular}

Table 3.10 indicates that majority of respondents 7 (77.78per cent) principals and 36 (66.67per cent) teachers, agreed that there existed non -tuition costs that makes FDSE inaccessible to some children in the Sub-County. Two (22.22per cent) principals and 18 (33.33per cent) teachers disagreed. The non-tuition costs identified by the respondents include cost of construction materials, uniforms, meals, boarding, athletics and travel expenses. Taking into consideration that some parents are extremely poor, many parents may be failing to enroll or retain their children in secondary schools because they cannot afford hidden costs of education. The findings agreed with Abagi (1997) who found that children whose parents could not afford costs of instructional materials and uniforms tend to go to school irregularly and in the long run dropped out of school.

Table 3.11 Parents/Guardians did not Provide Fees for their Children in Time

\begin{tabular}{lll}
\hline Rating & Frequency & Percentage \\
\hline Yes & 33 & 61.11 \\
No & 21 & 38.89 \\
Total & 54 & 100 \\
\hline
\end{tabular}

From Table 3.11, 33 (61.11per cent) of parents/guardians agreed that parents did not provide fees for their children in time while 21 (38.89per cent) disagreed. This could be an indicator that parents live in poverty which prevented them from educating their children since they could not meet the non-tuition cost nor pay fee in time. Parents also explained that some of them (parents) mismanaged the little earnings they got by buying things of less value compared to education. They explained that buying alcohol and drugs by many parents in the area made it impossible to pay school fees in time. Lack of interest in education made parents to prioritize other things more than paying fees for their children.

The findings of the study confirmed that costs of schooling in form of direct fees and indirect charges posed a challenge to universal education. The findings agreed with Bunyi and Kjersti (2000), who asserted that even when education is public and tuition free, school attendance still entailed outlays from family resources. The parental spending on education was hiked since the non-tuition fees like miscellaneous school charges, learning materials, transportation and boarding fees were incurred by families which eventually led to students dropping or not enrolling in secondary schools.

\subsubsection{Child Labour}

Information on child labour was gathered from principals and teachers. Specific statements were given to the principal and teacher respondents and were required to agree or disagree by ticking true or false.

Table 3.12 Children Drop Out of School for Paid Labour to Supplement Family Income

\begin{tabular}{lllll}
\hline & \multicolumn{3}{c}{ Principals } & Teachers \\
\cline { 2 - 5 } Rating & Frequency & Percentage & Frequency & Percentage \\
\hline True & 6 & 66.67 & 45 & 83.33 \\
False & 3 & 33.33 & 9 & 16.67 \\
Total & 9 & 100.00 & 54 & 100 \\
\hline
\end{tabular}

Teachers 45 (83.33per cent) and principals 6 (66.67per cent) agreed that boys withdrew from school to supplement family income while 9 (16.67per cent) and 3 (33.33per cent) of teachers and principals disagreed with the statement. Students in the discussions confirmed that some of the peers dropped out school to provide labour in the farms, family businesses, transportation of milk and other farm produce by bicycles to the market. This could indicate that child labour was still rampant in the Sub-County even after the government outlawed it. These findings are in agreement with a report by KIPPRA (2009) on Kenya Economy which showed that an increasing number of boys in Central Province are dropping out of school to seek salaried jobs to boost family income.

Table 3.13 Poorer Parents Withdraw Boys from School to Provide Labour in the Farm

\begin{tabular}{lllll}
\hline & \multicolumn{3}{c}{ Principals } & Teachers \\
\cline { 2 - 5 } Rating & Frequency & Percentage & Frequency & Percentage \\
\hline True & 2 & 22.22 & 11 & 20.37 \\
False & 7 & 77.78 & 43 & 79.63 \\
Total & 9 & 100.00 & 54 & 100 \\
\hline
\end{tabular}

Table 3.13 shows that majority of the teachers 79.63 per cent and principals 77.78 per cent disagreed that poor parents withdrew boys from school to provide labour in the farm while 20.37per cent teachers and 22.22per cent principals agreed with the statement. These findings contradict the previous findings shown on Table 4.12. This is an indication that boys drop out of school at their own will but not at the instigation of their parents. Students in 
their discussion explained that some students drop out of school since they had joined outlawed Mungiki sect. When probed further, students said that a person who joined Mungiki had to give some money as monthly contribution in order to support the group. Students feared attacks from the group if they failed to make the monthly contributions. They therefore dropped out of school to work for wages which would enable them make their contribution to the sect. The Ministry of Education Officials said that boys dropping out of schools in Mathioya were also triggered by the community culture of ownership. The culture of the community in the area is that properties were owned by men and therefore boys opted to leave school in order to work and own properties. The findings agreed with KIPPRA's (2009) argument that boys were more alert about happenings in the country and that graduates lack employment. Boys therefore made rational decision to earn income earlier than "wasting" time in school without guaranteed employment. According to KIPPRA, as boys grew up they are attracted to the culture of ownership and desired to have their own money and preferred working to pursuing education.

\subsubsection{Absence of Male Role Models}

The majority of the respondents disagreed that boys dropped out of school due to the absence of male teachers role models. Table 4.16 shows the results.

Table 3.16 Boys Dropout of School Due to the Absence of Male Role Models

\begin{tabular}{lllll}
\hline & \multicolumn{2}{c}{ Principals } & Teachers \\
\cline { 2 - 5 } Rating & Frequency & Percentage & Frequency & Percentage \\
\hline Agree & 0 & 0 & 14 & 25.93 \\
Disagree & 9 & 100 & 40 & 74.07 \\
Total & 9 & 100.00 & 54 & 100 \\
\hline
\end{tabular}

All the principals 100per cent and 40 (74.07per cent) of teachers disagreed with the statement. Principals and teachers explained that their schools had organized guidance and counseling sessions where male motivational speakers were invited. The speakers spoke to, motivated and encouraged boys to take their education seriously. They sensitized boys on dangers of indulging with Militia and Cultic groups. This could be an indicator that all teachers are well trained on how to deal with issues affecting both boys and girls in schools.

\subsubsection{Peer Influence, Drug and Substance Abuse on Education of the Boy-Child}

Peer influence, drug and substance abuse was a factor which was cited by majority of the students and parents in their group discussion and interviews respectively as a major factor influencing retention of the boy-child in the study Sub-County. Table 4.19 shows the results.

Table 3.19 Most of the Boys Drop Out of School Due to Peer Influence on Drugs and Substance Abuse

\begin{tabular}{lllll}
\hline & \multicolumn{3}{c}{ Principals } & Teachers \\
\cline { 2 - 5 } Rating & Frequency & Percentage & Frequency & Percentage \\
\hline Agree & 8 & 88.89 & 50 & 92.59 \\
Disagree & 1 & 11.11 & 4 & 7.41 \\
Total & 9 & 100.00 & 54 & 100 \\
\hline
\end{tabular}

Almost all the staff 8 (88.89per cent) and 50 (92.59per cent) of the principal and the teacher respondents respectively agreed with the statement that most of the boys dropped out of school due to peer influence on drugs and substance abuse. The high percentage of respondents agreed that peer influence was a major cause of dropout. This could be an indication that parents do not have ample time with their teenage boys and especially parents, who abuse alcohol, create a chance of forming relationship with friends who may show them directions that ruin their lives by engaging in risky behavior of alcohol and other drug abuse. It could also indicate that there is drug peddling in schools and that students influence each other in taking them. The findings agreed with Kairani (2008) who found that drug abuse and trafficking affect so many youths and that through peer influence many boys and girls dropped from schools. According to Kairani (Ibid), parents in regions with high poverty used local brew as source of income and involved their children in brew preparation, transportation and selling. Also most of the student ended up being employed as drug traffickers which led to their expulsion from schools. Indeed, some parents are drug traffickers.

\subsubsection{Household and Community Related Factors}

The study sought to determine and analyze household and community related factors influencing retention of the boy-child in Mathioya Secondary Schools. The researchers sought views from students, teachers and principals of the sampled schools, parents/guardians and Ministry officials within the study Sub-County. Under this category variables were examined by providing specific statement to the principal and teacher respondents to tick accordingly.

\subsubsection{Value Attached to Education by the Community}

When asked about the effect of community value of education had on retention of the boy-child the responses were as in Table 3.20. 
Table 3.20 Value Attached to Education by a Community Play a Major Role in Retention of the Boy-Child in Secondary School.

\begin{tabular}{llclc}
\hline & & Principals & \multicolumn{2}{c}{ Teachers } \\
Rating & Frequency & Percentage & Frequency & Percentage \\
\hline Strongly agree & 2 & 22.22 & 19 & 35.19 \\
Agree & 4 & 44.44 & 18 & 33.33 \\
Disagree & 2 & 22.22 & 9 & 16.67 \\
Strongly disagree & 1 & 11.11 & 8 & 14.81 \\
\hline Total & 9 & 99.99 & 54 & 100.00 \\
\hline
\end{tabular}

Majority of the principals and teachers 66.66 per cent and 68.52per cent respectively agreed that the value attached to education by community play a major role in retention of the boy-child in secondary education. Teachers explained that parents did not give education first priority and those who did majority preferred educating the girl-child to the boy-child. Parents view the girl-child as assets that if well educated, she would marry a wealthier family which would pay a better dowry. Some of the interviewed parents said that once an educated girl got employed she would remember parents and visit them frequently or send them money for their spending. Some of the interviewed parents said that boys were seen to be stronger, more intelligent and powerful than girls and therefore did not need as much protection as girls. The boys were socialized not to display their weaknesses and therefore suffered in silence. The Mathioya Community viewed girls to be more vulnerable to dropping out of schools than boys. This indicated that girls were more motivated to learn than boys and in turn more boys dropped out of school. This indicated that the attitude that the society has about masculinity and the ways in which boys understood their masculine identities played a key role in minimal attention given to the issue of education and the boy-child in the study Sub-County. The findings agreed with Karugu (2008) who established that more boys dropped out of schools more than girls. The findings also agreed with a report by KIPPRA (2009), which found that parents in Central Province were shifting from boys' education to that of girls. Macharia (2009), also stated that the way in which masculine identities were socially constructed was an important factor that militated boys against enrolment and retention in schools.

\subsubsection{Roles Assigned to the Boy-Child at Home}

Principals and teachers were expected to state whether the roles assigned to the boy-child at home made them drop out of school. Table 3.21 presents the responses.

Table 3.21 Roles Assigned to the Boy-Child at Home Make him Dropout of Secondary School

\begin{tabular}{lllll}
\hline Rating & Frequency & $\begin{array}{c}\text { Principals } \\
\text { Percentage }\end{array}$ & Frequency & $\begin{array}{c}\text { Teachers } \\
\text { Percentage }\end{array}$ \\
\hline Strongly agree & 0 & 0.00 & 11 & 20.37 \\
Agree & 3 & 33.33 & 15 & 27.78 \\
Disagree & 5 & 55.56 & 21 & 38.89 \\
Strongly disagree & 1 & 11.11 & 7 & 12.96 \\
\hline Total & 9 & 100.00 & 54 & 100.00 \\
\hline
\end{tabular}

More than half 6 (66.67per cent) and 28 (51.85per cent) of principals and teachers respectively disagreed. This shows that roles assigned to boys at home such herding, attending the farm, milking and feeding livestock had little influence on their retention in secondary education. However, interviewed parents explained that some single parents who left for urban centres left their children back in the village unattended. This forced school children to undertake household chores like caring for their young siblings, fetching water and working in the farm to earn income. These children eventually dropped out of school.

Parent interviewees explained the effect of HIV/AIDS as a major cause of drop-out from schools. Children whose parents had died or ailed from AIDS were forced to drop out of school to take parental responsibilities such employment and care for their young siblings. Some of the children contracted HIV/AIDS since they lacked skills to protect themselves. HIV/AIDS drained family finances since medicine for the treatment are costly and most income and savings are used up in treatment. The family become poor and cannot afford other necessities of life including education. This led to the boy-child dropping out of school due to lack of school fees and other learning requirements. Parents further explained that teachers also died or left work due to HIV/AIDS. This made some subjects to remain untaught and triggered drop out of the boy-child from school. Some boys also suffered from HIV/AIDS especially those who engaged in drug abuse. Some died while others became too weak to learn and eventually dropped out of school. The findings agreed with Republic of Kenya (2007) which stated that attrition rate for teachers and education officers was rising and 1.8per cent of teachers were dying in the country annually. Kisirikoi et al (2008), also found that HIV/AIDS contributed to high teacher absenteeism and eventually learners dropped out of school. 


\subsubsection{Influence of Militia Group (Mungiki) on Retention of the Boy-Child in Mathioya.}

Principals and teachers were expected to agree or disagree whether Mungiki had influence of retention of the boychild education in the study Sub-County. Their responses are shown in Table 3.22.

Table 3.22 Influence of Militia Group (Mungiki) Contributes to Low Access and Retention of the Boy-Child in the Mathioya.

\begin{tabular}{lllll}
\hline Rating & Frequency & $\begin{array}{c}\text { Principals } \\
\text { Percentage }\end{array}$ & Frequency & $\begin{array}{c}\text { Teachers } \\
\text { Percentage }\end{array}$ \\
\hline Strongly agree & 2 & 22.22 & 29 & 53.70 \\
Agree & 5 & 55.56 & 10 & 18.52 \\
Disagree & 2 & 22.22 & 13 & 24.07 \\
Strongly disagree & 1 & 11.11 & 2 & 3.70 \\
\hline Total & 9 & 100.00 & 54 & 99.99 \\
\hline
\end{tabular}

Out of 9 principals 7 (77.8per cent) agreed while 3 (33.33per cent) disagreed. Of the teacher respondents 72.2per cent agreed while 27.7per cent disagreed. The findings from the principals and teachers indicated that Mungiki group contributed to low retention of the boy-child in secondary education in the Sub-County. The influence of Mungiki was also cited by students and parents. They explained that boys were recruited to join the sect before or immediately after completing class 8 , some would join while some would discard it. Those who discarded the group lived in perpetual fear since they received threats from the group members and eventually dropped out of the schools or refused to enroll in secondary schools. The findings agreed with Macharia (2009) who explained the influence of Mungiki on education: "boys dropped out of schools since they were promised easy life without having to work; absented themselves from school; performed poorly because they lost interest in school, lacked vision; were undisciplined especially disrespecting their parents and teachers, and engaged themselves in drug abuse and trafficking".

In order to gather more information teachers and principals were asked to identify any other household and community related factors that influenced retention of the boy-child in secondary schools within the Sub-County. They gave the following responses in order of priority as indicated in Table 3.23.

Table 3.23 Household and Community Related Factors that Influence Access and Retention of the Boy-Child in Mathioya Sub-County

\begin{tabular}{lll}
\hline Factors & Frequency & Percentage \\
\hline HIV/AIDS scourge & 24 & 36.9 \\
Family break ups & 22 & 33.8 \\
Illiteracy in the household & 8 & 12.3 \\
Over emphasis and over protection of the girl-child & 6 & 9.2 \\
Modern lifestyle of internet and television program & 5 & 7.7 \\
\hline Total & 65 & 100
\end{tabular}

Most respondents 24 (36.9per cent) identified HIV/AIDS scourge followed by family break ups 22 (33.8per cent) and illiteracy in the household 8 (12.3per cent). Over emphasis and over protection of the girl-child 6 (9.2per cent) and modern lifestyle of internet and television program had the same number of respondents 5 ( 7.7 per cent) HIV/AIDS drained the family financial resources through paying for costly treatment rather than paying fee for the boy-child. According to the respondents, family break up had become an issue in education. Single parents were unable to raise fee and other learning materials for their children. Respondents explained that over emphasis and over protection of girl-child especially in education issues demotivated boys who felt neglected and eventually dropped out of school. The findings agreed with KIPPRA (2009), which found that parents in Central Province shifted priority from boys' education to that of girls. The findings also agreed with Simiyu (2001), who found that proponents of gender equality had aggravated the situation by adopting an openly discriminatory stance against boy-child. According to Simiyu (2001) gender activists put great emphasis of welfare of girl-child while the boychild was tottering on blink of extinction.

The modern lifestyle of internet and television influenced boys' education because they exposed themselves to dirty programs such as pornography and dirty dancing which polluted their mind. This made the learners not to concentrate in their studies, give little time to studies, eventually they performed poorly, got discouraged and dropped out of school. These findings agreed with Kisirikoi et al (2008), who stated that young people were increasingly exposed to ways of life of other countries through mass media and copied the same. Therefore, young people needed to be monitored on what they were exposed to in order to avoid negative influences.

\subsubsection{Cultural Beliefs and Community Practices that Affect Education of the Boy-Child}

Teachers were asked to identify cultural beliefs and community practices that affected education of the boy-child in the study Sub-County. Majority of the teachers 39 (72.22per cent), who responded to the question were not aware of any that had effect on retention of the boy-child. However, 15 (27.78per cent) associated retention in 
Mathioya with stereotypes like once a boy undergoes initiation to adulthood he should be left free to make decision because he is taken to be responsible, the well up people in the community had not acquired their wealth through education and that there were other channels of getting rich. Such beliefs discouraged boys from continuing with education in Mathioya. The attitudes people have on any issue is quite instrumental on their behavior in relation to such issues. Teachers said that parents inculcated bad beliefs to their children which were detrimental to their education. The findings also disagreed with Kisirikoi et al (2008) by stating that parents and their children perceived education as a vehicle which would enable them achieve social mobility. They anticipated progress after education but lack of this benefit caused frustration and many school leavers considered formal education as useless to their livelihoods.

\subsubsection{Roles Played by Gender Activist on the Boy-Child Education in Mathioya Sub-County}

Principals, teachers and Ministry Officials were asked to comment on the roles played by gender activist on the boy-child education in Mathioya. Majority (87.5per cent) of the respondents were not aware of any gender activists addressing issues of the boy-child education in Mathioya, while 12.5per cent of the respondents indicated that there were gender activists. USAID and NACADA were known to be paying school fees for some students and rehabilitated boys affected by drug and substance abuse. Besides, they identified guidance and counseling session and motivational speakers which involved internal and external facilitators who strengthened guidance and counseling departments and improved retention of learners in schools.

\subsubsection{Ways of Improving Retention of the Boy-Child in the Sub-County}

The study sought suggestions on how to improve retention of the boy-child in the Sub-County. When asked the role of government, parents, teacher principal, community and students would play to alleviate the problem, 65 respondents who comprised of 2 ministry officials, 9 principals and 54 teachers gave various suggestions as follows: Majority of the respondents 62 (95.38per cent) suggested that the boy-child should be given equal chance with the girl-child. The findings confirm a report by Simiyu (2001) that showed that gender activists put great emphasis on the welfare of the girl-child while the boy-child is tottering on blink of extinction. A report by KIPPRA (2009), found that parents in Central Province were shifting priority form boys' education to that of girls. This aggravated the situation of low access and low retention of the boy-child in secondary schools. Some teachers felt that the government should organize public barazas where community would be sensitized on importance of educating both boys and girls.

Majority of the principals (77.78per cent) and teachers (72.22per cent) agreed that influence of Militia group like Mungiki contributed to low access and low retention of the boy-child in schools in Mathioya. In order to alleviate the problem, 6 (66.67per cent) of the principals and 47 (87.04per cent) of the teachers suggested that, the government should intensify security in order to eliminate the unlawful sect within the Sub-County.

Among the respondents 55 (84.62per cent) suggested that the government should ensure adequate funding of education. The Free Secondary Education (FDSE) should be made completely free without involvement of parents in the cost sharing. According to Kisirikoi et al (2008), the cost sharing makes many learners from poor households to terminate their education early without sufficient skills to meet challenges of the modern world. Other teachers suggested that bursary awards should be increased and awarded to the needy students without corruption. This would ensure that children whose parents failed to enroll in secondary schools due to guise of poverty join and complete the cycle without any wastage.

Majority of teachers 38 (70.37per cent) felt that more boys' boarding school should be established. These schools would retain boys in school and improve their participation since they would stop trekking for long distances. The findings agreed with FAWE, (1997) that distances between home and school deter enrolment, regular attendance and early drop out. Mathioya has 25 secondary schools of which only 2 are boys' boarding schools, 5 girls boarding and 18 mixed day schools indicating that majority of the students walk for long distance where students may be exposed to negative influences. They may also experience challenges of co-education schools.

Most of teacher 46 (85.19per cent) indicated that the staffing of the schools should be improved in order to ensure quality teaching and learning within the secondary schools. The findings confirmed a report by KIPPRA, (2009) which indicated that there was a serious shortage of teachers in Kenyan schools. Teachers indicated that the high workload and large classes compromised the quality of teaching and learning offered in secondary schools.

Many respondents 51 (78.46per cent) felt that in order to improve retention of the boy-child, all education stakeholders should embrace guidance and counseling of the boy-child either in school or homes. They felt that school principals should establish regular mentorship programmes where role models from the community within and without school to speak, motivate and encourage boys to take education seriously and stop indulging in militia and cultic group influences. Some respondents also suggested that teachers and parents should present themselves in acceptable manner in order to be role models to the learners. This would encourage boys to maintain high discipline, work hard in education and eventually retention in school would be improved. Households could also be supported in lucrative economic activities to enable support their children. 


\subsection{Conclusions of the Study}

From the findings, the study concludes that low retention affected boys more than girls in Mathioya. The most prominent causes of declining rates of retention of boys in public secondary schools in the Sub-County were poverty, children being orphaned due to HIV/AIDS pandemic, negative attitude towards education, influence from militia groups, negligence of the boy-child education, peer influence, drug and substance abuse, child labour, poor performance, indiscipline, family break ups, transfer of children from one public schools to another and to private academies. The existence of a major shortage of teachers also had a major effect on retention of students in secondary schools in the Sub-County. These factors pose a threat towards achievement of retention of learners in secondary schools.

\subsection{Recommendations of the Study}

Based on the findings, the researchers recommends the following:

1. The government should introduce school feeding programmes and ensure that it is maintained throughout the term so that students do not drop out due to their inconvenience.

2. Government, National and County, should establish more single sex boarding schools to ensure that students are protected from challenges facing day and mixed schools. This would also ensure more students are retained in secondary schools in order to improve their participation in schooling.

3. The well up and successful people from Mathioya Sub - County could be encouraged to provide motivation talks in schools at the county.

4. Policies of readmission of dropouts should be formulated especially those touching on boy child to reduce wastage in education and make education beneficial to the country and the society.

5. Education of stakeholders should embrace guidance and counseling of the boy-child either in schools or homes. Role models should be used to make visitations to schools to encourage learners in education.

6. Teachers Service Commission (TSC) should post more male teachers in the sub-county

7. All the stakeholders should join forces and deal with the Mungiki/Militia group

\section{REFERENCES}

Abagi, O. \& Odipo, G. (1997). Efficiency of Primary Education in Kenya. Situational Analysis Implication. IPAR Discussion Paper No. 00497/95. Nairobi: Regal Press.

Best. J.W. \& Khan. J.V. (1993). Research and Education. Boston, Allyn and Bacon Inc.

Borg, W.R. \& Gall, M.D. (1989). Educational Research: An Introduction, (5 ${ }^{\text {th }}$ Edition). New York: Longman.

Bruns, B; Mingat, A \& Rokotomalala, R. (2002). Achieving Universal Primary Education by 2015. A chance for every child. Washington D.C: World Bank Publications.

Children Acts, (2001). Government Printers. Nairobi.

Curle, A. (1973). Education Problems of Developing Societies. Washington: Raeger Publishers.

Farrant, J.S. (1985). Principles and Practice of Education, Longman Group Limited Essex, England, 1985. New Edition.

Fatima, K. \& Jyotsna, J. (2006). Boys Underachievement in Education Commonwealth.

FAWE, (2002). The ABC of Gender Responsive Education Policies: Guidelines for Analysis and Planning. Forum for African Women Educationists, FAWE Newsletter. Nairobi

Grace B. \& Kjersti, O. (2000). Girls Education. UNICEF 2000.

Johnson, A. (1996). Theoretical Model of Economic Nationalism in Developing States. London: George Allen and Undwin Ltd.

Kairani, E.W. (2008). Factors Influencing Transition Rates from Primary to Secondary and Retention in Secondary Schools in Gichugi Division of Kirinyaga Sub-County, Kenya. Unpublished Master of Education Project, Kenyatta University Nairobi.

Karugu, H.T. (2008). Factors Affecting Boy-child Access and Detention in Public Schools in Kiambu Sub-County. Unpublished Master of Education Project, Kenyatta University, Nairobi.

Kisirikoi, F, Malusu, J. \& Wachira, L. (2008). Distinction: Primary School Teacher Education. Nairobi: Kenya Literate Bureau.

Macharia, M.W. (2009). Factors influencing Enrolment and Retention of Boys in Secondary Schools of Kiambaa Division, Kiambu East, Central Province, Kenya. Unpublished Master of Education Project, Catholic University of Eastern Africa

Mba, P.O. (1991). Element of Special Education. Ibaden: Cedal Publication.

Mbilinyi, D.A.S. (2003). Equity in Learning: The Gender Dimension: A DEA Biennial. Meeting Mauritius Grand Baie.

Mugenda, O.M. \& Mugenda, A.G. (2003). Research Methods: Qualitative and Quantitative Approaches, Nairobi: Acts Press.

MOEST (2005). Sessional Paper No. 1 of 2005 on A Policy Framework for Education, Training and Research. 
Nairobi: Government Printers.

Ngau, M. M. (1991). Grade Retention and school dropouts in Kenyan Primary Schools: A critical Analysis and Equity Issues in Education. Unpublished Doctor of Philosophy Dissertation. Stanford University.

Njeru E. \& Orodho J.A. (2003). Access and Participation in Secondary Education in Kenya. Emerging Issues and Policy Implication IPAR Discussion Paper series No. 037/2003. Nairobi: 1PAR.

Nyakwara, B. (2009). Research, Monitoring and Evaluating Made Simple: Blesmo Research and Publications, Nairobi, Kenya.

Orodho, J.A. (2008).Techniques of Writing Research Proposals and Reports in Education and Social Sciences: Kenezja HP enterprises Maseno.

Orodho, J.A. (2009). Elements of Education and Social Science Research Methods. Maseno, Kenya, Kanezja Publisher.

Oyuke, J. (2000, $8^{\text {th }}$ March). Child Labour Hampers Growth. East African Standard, pp.13.

Psacharopoulos, G. \& Woodhall, M. (1985). Education and Development: and Analysis on Investment Choices. New York: Oxford University Press.

Prime parenting (July, 2009). Premier Magazine for Eastern Africa. Executive image Limited. Public Relations Corporate Communication

Republic of Kenya (1964). Kenya Education Commission on Education Report (Ominde Report). Nairobi, Government Printers.

Republic of Kenya. (2003). National Action Plan on Education for All (2003-2015), Nairobi, Government Printers. Republic of Kenya. (2007). Secondary Education Strategy. Nairobi: Government Printers.

Sherman, T. \& Wood, H. (1982). Traditional and Radical Perspectives. London: Harber and Raw Publishers.

Sifuna, D. (1980). Short Essays on Education in Kenya. Nairobi: Kenya Literature Bureau.

Simiyu, B. (2001, $8^{\text {th }}$ July). The Neglect of the Boy-Child. Kenya Times, pp.15.

Theuri, A. W. (2004). An Analysis of Internal Efficiency in Second Level. Learning Institution in Slums Areas of Nairobi Province, Kenya, Unpublished Master of Education Thesis, Kenyatta University

UNESCO (2000). Planning for Education in Context of HIV/AIDS. Paris: UNESCO Office.

UNESCO (2002). The Challenge of Achieving Gender Parity in Basic Education. UNESCO - Pans.

UNESCO (2003). HIV and Education: HIV/AIDS and the Role of Education Service Commissions. Nairobi Office.

UNESCO (2005). Education For All. The Quality Imperative Global Monitoring Report. Paris.

UNICEF, (1998) A Rapid Assessment of Status of Girls Education in Six UNICEF Focus Sub-Countys: Nairobi, Baringo, Mombasa, Garissa, Kwale and Kisumu. Nairobi: The Collaborative Centre for Gender and Development.

Wainaina, G. (2006). An Inequality Perspective of Education Structure and Performance in Kenya. In Readings on Inequality in Kenya: Sectoral Dynamics and Perspective. Nairobi: Society for International Development pp. 157-194.

Wamahiu, S. P. \& Karugu, A.K.(1995). Qualitative Research in Education. In Mwiria, K. and Wamahiu, S.P. (Editors). Issues in Educational Research in Africa. Nairobi: East African Educational Publishers.

Wiersma, W. (1986). Research Methods in Education: An Introduction, $4^{\text {th }}$ Edition, Massachusetts, Allyn and Bacon, Inc. 